\title{
Anaemia in systemic lupus erythematosus: aetiological profile and the role of erythropoietin
} Michalis Voulgarelis, Styliani I G Kokori, John P A Ioannidis, Athanasios G Tzioufas,
Despina Kyriaki, Haralampos M Moutsopoulos anaemia (AHA), iron deficiency anaemia (IDA), drug induced myelotoxicity, and anaemia of chronic renal failure are probably not uncommon. ${ }^{1-4}$ Other types of anaemia such as pure red cell aplasia (PRCA), pernicious anaemia (PA), myelofibrosis, sideroblastic anaemia, haemophagocytic syndrome, and thrombotic microangiopathy are seldom diagnosed..$^{5-12}$

The anaemias of chronic disease are typically hypoproliferative processes. ${ }^{13}$ Reduced erythropoietin (Epo) activity, usually the result of reduced production ${ }^{14}$ and resistance to Epo action on erythroid cells, ${ }^{15}{ }^{16}$ plays a part in the pathogenesis of ACD observed in various systemic autoimmune disease. Furthermore, recent studies have shown that resistance to Epo action in systemic autoimmune disease can be attributable to autoantibodies against Epo (anti-Epo). ${ }^{17}{ }^{18}$ The extent of reduced production and resistance to Epo in SLE patients with ACD and other causes of anaemia is not known.

Knowledge on the profile of anaemia in the setting of SLE has been gleaned from a number of series with small number of patients. The association of specific causes of anaemia with specific immunological and clinical manifestations of SLE and their prognosis is not well known from adequately sized studies. Therefore we conducted a prospective study to evaluate in a large cohort of SLE patients the causes of anaemia and their associations with other SLE manifestations and to determine the extent of reduced production and resistance to Epo attributable to anti-Epo autoantibodies in different types of SLE anaemia.

\section{Methods}

PATIENTS

A prospective study was carried out in the Department of Pathophysiology, School of Medicine, National University of Athens, from January 1996 until February 1999. One hundred and thirty two patients who had anaemia and fulfilled at least four of the revised American College of Rheumatology (ACR) criteria for the diagnosis of SLE ${ }^{19}$ were studied. Anaemia was defined by haemoglobin of 12 $\mathrm{g} / \mathrm{dl}$ or less for women and $13.5 \mathrm{~g} / \mathrm{dl}$ or less for men. ${ }^{20}$ No patient had infection at the time of anaemia evaluation.

For each patient we completed a lupus/ anaemia data file with three sections. The first section included the criteria of $\operatorname{SLE}^{19}$ and the blood cell counts. The second section included a lupus activity index using the European Consensus Lupus Activity Measurement (ECLAM) scale ${ }^{21}$ at the time of study, history
Anaemia is a common clinical finding in patients with systemic lupus erythematosus (SLE). ${ }^{1-3}$ The most common form of anaemia in these patients is that of chronic disease (ACD), ${ }^{1}$ however autoimmune haemolytic 
and physical examination of the patients and corresponding treatments. The third section focused on the disease evolution during follow up looking at the time to resolution of anaemia in subsequent visits. The typical patient monitoring included periodic recording of clinical and laboratory disease manifestations at four to six week intervals.

LABORATORY DETERMINATIONS FOR ANAEMIA

In addition to clinical examination, in each patient routine laboratory tests were used to assess blood cell counts, red cell indices, reticulocytes, erythrocyte morphology, erythrocyte sedimentation rate, serum haptoglobin (turbiquant test, Behring Diagnostics $\mathrm{GmbH}$ ), serum iron (Bathophenanthroline direct method, Wako Chemicals $\mathrm{GmbH}$ ), serum ferritin (Microparticle Enzyme Immunoassay, Abbott AXSYM SYSTEM), electrophoresis of haemoglobin and the direct Coombs test (Ortho Diagnostics Inc, Raritan, New Jersey). Renal and hepatic biochemical examination was performed in all patients.

Operationally, anaemia may be divided into those conditions with impaired red cell production (marrow suppression, nutrient deficiency) and those with increased red cell destruction (haemolysis, hypersplenism) or blood loss. Measurement of reticulocyte production (reticulocyte index) has been used to make this distinction and it was the major step for determination of causes of anaemia. IDA was defined by serum ferritin below $20 \mu \mathrm{g} / \mathrm{dl} .{ }^{22}$ We used a similar lower level for normal ferritin for both sexes. PA was defined by serum vitamin B12 less than $180 \mathrm{pmol} / 1$ together with one or more of the following: an abnormal Schilling test result that was corrected on repeating the test with exogenous intrinsic factor, or the presence of anti-intrinsic factor antibody in the blood. ${ }^{23}$ Classic criteria for thalassaemia, ACD, AHA, and PRCA were used. ${ }^{24-27}$

Sera from the last 100 consecutive patients were kept at $-80^{\circ} \mathrm{C}$ for determination of Epo and anti-Epo antibodies. Serum Epo was evaluated by a commercially available radioimmunoassay (Incstar Cor, Stillwater, $\mathrm{MN}$ ) according to the manufacturer's instructions (normal range: $17.7 \pm 7.5 \mathrm{mU} / \mathrm{m}$ ). To define Epo levels as appropriate or inappropriate for a given degree of anaemia, we used a control group of 20 subjects who had uncomplicated IDA without any other disease process. Serum anti-Epo antibodies were determined using an enzyme linked immunosorbent assay (ELISA) and purified recombinant human Epo as antigen. ${ }^{17}$ In our previous study ${ }^{17}$ it was shown by homologous inhibition experiments, that the assay for the detection of the anti-Epo antibodies was highly sensitive and specific. In addition there was no influence of hypergammaglobulinaemia in the final optical density. No patients received recombinant Epo for therapeutic use.

Bone marrow smears were performed where indicated. Prussian blue staining of marrow iron was performed to evaluate iron deposition in individual erythroblast and reticuloendothelial iron stores. The iron stores in the smears were classified from zero to $4+$. Zero and $1+$ iron was classified as iron deficiency. Other laboratory data were obtained as required by the clinical condition of the patients.

LABORATORY EVALUATION OF IMMUNOLOGICAL PARAMETERS

In each patient the following SLE related serological parameters were determined: C3 and C4 components of complement (by nephelometry); antinuclear antibodies (ANA) (by immunofluorescence in Hep-2 substrate/ Innova, San Diego, CA); antibodies to the cellular antigens Ro/SS-A, La/SS-B, Sm, and U1RNP (by counterimmunoelectrophoresis); antibodies to double stranded DNA $(\mathrm{dsDNA})^{28}$ and to $\operatorname{IgG} / \operatorname{IgM}$ cardiolipin $(\mathrm{aCL})^{29}$ (by ELISA).

STATISTICAL ANALYSIS

Comparisons of proportions of patients with various immunological and clinical parameters between the four major groups of causes of anaemia (ACD, IDA, AHA, and other causes) was performed with the $\chi^{2}$ test. For multiple independent parameters, we performed multivariate logistic regression. Continuous measures were compared with Kruskal-Wallis one way analysis of variance.

To assess the outcome of anaemia for different causes during prospective follow up, Kaplan-Meier plots for the time to correct the haemoglobin $(12 \mathrm{~g} / \mathrm{dl}$ for women and $13.5 \mathrm{~g} / \mathrm{dl}$ for men) were performed for each type of anaemia. The plots were compared with the log rank test. The effect of background treatment (before study entry and after study entry) was also assessed with similar time to even analyses.

The relation between ECLAM score and haemoglobin concentration in each group and across the study cohort was evaluated with linear regression. Epo responses at different levels of haemoglobin were also evaluated with linear regressions using the logarithm of Epo as the dependent variable and haemoglobin concentrations as the independent variable. A group of 20 normal women with IDA caused by increased menstrual blood loss, in the absence of any other complicating disease who had erythropoietin levels measured in our laboratory were used to generate the control curve and predicted values thereof for different levels of haemoglobin. Inadequate Epo response was also defined as an observed:predicted ratio of $\operatorname{logEpo}$ of 0.74 or less. ${ }^{30}$ All analyses were performed in Advanced SPSS (version 6.1, Chicago 1994) and all $\mathrm{p}$ values are two tailed.

\section{Results}

STUDY COHORT: CAUSES AND SEVERITY OF ANAEMIA

One hundred and thirty two cases of anaemia (122 women, 10 men) from among a total of 345 screened SLE patients were included in the analysis. The estimated prevalence of anaemia in SLE patients based on our study cohort was $38 \%$. The identified causes of anaemia were: $\operatorname{ACD} n=49(37.1 \%)$, IDA $n=47(35.6 \%)$, AHA $n=19$ (14.4\%), and other causes $n=17$ $(12.9 \%)$. Most of the female patient group with 
Table 1 Immunological and clinical parameters that differ across different causes of anaemia

\begin{tabular}{|c|c|c|c|c|c|}
\hline \multirow[b]{3}{*}{ Causes } & \multicolumn{5}{|c|}{ Immunological and clinical parameters } \\
\hline & \multicolumn{2}{|c|}{$\begin{array}{l}\text { Anticardiolipin } \\
\text { antibodies }\end{array}$} & \multirow{2}{*}{$\begin{array}{l}\text { Low C3 } \\
\text { levels }\end{array}$} & \multirow[b]{2}{*}{ Anti-dsDNA } & \multirow{2}{*}{$\begin{array}{l}\text { Lupus } \\
\text { nephritis }\end{array}$} \\
\hline & $\operatorname{Ig} G$ & $\operatorname{Ig} M$ & & & \\
\hline $\mathrm{ACD}$ & $21 / 46$ & $13 / 46$ & $15 / 47$ & $32 / 49$ & $28 / 49$ \\
\hline IDA & $9 / 42$ & $7 / 43$ & $4 / 47$ & $14 / 45$ & $12 / 47$ \\
\hline AHA & $13 / 19$ & $12 / 19$ & $7 / 18$ & $17 / 19$ & $7 / 19$ \\
\hline Other causes & $5 / 17$ & $5 / 17$ & $1 / 17$ & $8 / 17$ & $14 / 17$ \\
\hline
\end{tabular}

ACD: anaemia of chronic disease; IDA: iron deficiency anaemia; AHA: autoimmune haemolytic anaemia; anti-dsDNA: anti double stranded DNA; lupus nephritis is defined according to WHO anaemia; anti-dsDNA: anti double stranded DNA; lupus neph
classification $^{31}$; low complement $\mathrm{C} 3$ levels: less than $50 \mathrm{mg} / \mathrm{dl}$.

IDA had a history of increased menstrual blood loss and all the IDA patients had negative fecal occult blood testing. The last group includes $\beta$ thalassaemia trait $(n=3)$, cyclophosphamide induced myelotoxicity $(\mathrm{n}=2)$, chronic renal failure $(n=8)$, thrombotic thrombocytopenic purpura (TTP) $(n=1)$, PRCA $(n=1)$, PA $(\mathrm{n}=1)$, and disseminated intravascular coagulation $(n=1)$. Three patients also had a second cause of anaemia: one patient with chronic renal failure and one patient with ACD also had PA and one patient with IDA also had cyclophosphamide induced myelotoxicity.

Among the 132 patients, the mean age at onset of SLE was 30.2 (SD 14.3), the mean age at the time of the study was 35.9 (SD 14.8), the mean haemoglobin was $10.1 \mathrm{~g} / \mathrm{dl}$ (SD 1.44), and the mean ECLAM score was 4.1 (SD 2.1).

The four main groups differed significantly in the ECLAM score with the group of ACD having patients with higher ECLAM scores (mean 5.2, SD 1.9), followed by the group of other causes (mean 4.3, SD 2.0) and the groups of AHA (mean 3.1, SD 1.6) and IDA (mean 3.1, SD 2.1) $(p=0.01)$. The four groups did not differ significantly in age at SLE onset or at the time of study, although ACD patients tended to be on average about seven years older.

Overall there was significant heterogeneity in the severity of anaemia as defined by the haemoglobin level, among the four groups $(p<0.001)$ with IDA cases being the mildest on average. IDA had a mean haemoglobin of $10.87 \mathrm{~g} / \mathrm{dl}$ (SD 0.91), as compared with 9.94 (SD 1.31) for ACD, 8.99 (SD 1.51) for AHA and 9.64 (SD 1.80) for the group of other causes. Of 14 cases with haemoglobin $<8 \mathrm{~g} / \mathrm{dl}$, there were five AHA, seven ACD, one PRCA and one TTP. In regression analyses, the level of haemoglobin was influenced by ECLAM with a decrease of $0.14 \mathrm{~g} / \mathrm{dl}(\mathrm{p}=0.016)$ per each one point increase in ECLAM. However, ECLAM was a significant predictor only within patients with IDA $(0.13 \mathrm{~g} / \mathrm{dl}(\mathrm{p}=0.041))$ and in patients with other causes of anaemia $(0.48$ $\mathrm{g} / \mathrm{dl}(\mathrm{p}=0.096))$, not among ACD $(\mathrm{p}=0.98)$ and AHA $(\mathrm{p}=0.94)$.

Bone marrow examination was performed in 31 patients with ferritin value $\geqslant 20 \mu \mathrm{g} / \mathrm{dl}$ and serum iron $\leqslant 60 \mu \mathrm{g} / \mathrm{dl}$ in which renal, endocrine, or hepatic disease had been excluded. None of the patients showed stainable iron in the eythroblasts and all presented normal or increased iron stores. The latter finding suggested the diagnosis of ACD for all these cases.

ASSOCIATIONS OF DIFFERENT CAUSES WITH CLINICAL AND IMMUNOLOGICAL PARAMETERS The prevalence of several immunological parameters differed significantly across different groups (table 1). Anticardiolipin antibodies (aCL) were most common in AHA and unusual in IDA ( $p=0.003$ for IgG, $p=0.003$ for $\operatorname{IgM}$ across the four groups). Low levels of complement $\mathrm{C} 3$ and $\mathrm{C} 4$ (less than $50 \mathrm{mg} / \mathrm{dl}$ and less than $20 \mathrm{mg} / \mathrm{dl}$, respectively) were also most common in AHA, and they were also seen in $\mathrm{ACD}$, but were uncommon in the other two groups ( $p=0.003$ for $C 3, p=0.09$ for $C 4$ across the four groups). Anti-dsDNA antibodies were seen in almost all patients with AHA, and in most patients with ACD, but were less common among patients with IDA or other causes of anaemia ( $p<0.001$ across the four groups). CRP concentrations were not related with severity of anaemia among the four groups. Furthermore, lupus nephritis ${ }^{31}$ was also seen in different proportions in the four groups $(p<0.001)$ and it was uncommon in IDA, not very common in AHA and common in ACD. All these patients underwent percutaneous renal biopsy. In the ACD group with lupus nephritis (28 patients) the histological findings for the patients according to WHO classification were as follows: class I $n=1$, class II $n=7$, class III $n=15$, class IV $n=2$, class $V$ $\mathrm{n}=3$. The main groups did not differ significantly in other clinical manifestations.

EPO RESPONSE AND ANTI-EPO ANTIBODIES

Overall, there was no difference in the average levels of Epo among different causes of anaemia ( $p=0.99$ by Kruskal-Wallis ANOVA) for the 99 patients where Epo was measured. The mean Epo level in each group was as follows: ACD $36.9 \mathrm{mU} / \mathrm{ml}$ (SD 34.5), IDA $36.8 \mathrm{mU} / \mathrm{ml}$ (SD 35.5) and AHA $41.8 \mathrm{mU} / \mathrm{ml}$ (SD 49.7). The Epo levels were not significantly influenced by ECLAM in any of four groups ( $p=0.74,0.42 .0 .24,0.27$ respectively).

Of 100 patients tested, anti-Epo antibodies were detected in 21 . There was heterogeneity in the prevalence of anti-Epo among different causes: 13 of 34 for ACD, 6 of 39 for IDA, 2 of 16 AHA, 0 of 11 others $\left(p=0.015\right.$ by $\left.\chi^{2}\right)$. AntiEpo antibodies were most common in anaemia of chronic disease and uncommon in other cases. Even the few cases of IDA with anti-Epo antibodies also tended to have high ECLAM scores. Within the IDA group, patients with anti-Epo had significantly higher ECLAM compared with patients without anti-Epo antibodies (mean $4.7 \approx 2.7, \mathrm{p}=0.039$ by $t$ test). Patients with antiEpo antibodies had higher ECLAM scores also across all four groups (mean 5.2 (SD 1.9) v 3.6 (SD 2.2)). In a logistic regression model, anaemia of chronic disease and ECLAM score were independent predictors of having anti-Epo antibodies. The odds ratios were $3.1(\mathrm{p}=0.041)$ in the presence of anaemia of chronic disease, and 1.27 per each ECLAM point $(\mathrm{p}=0.055)$. 


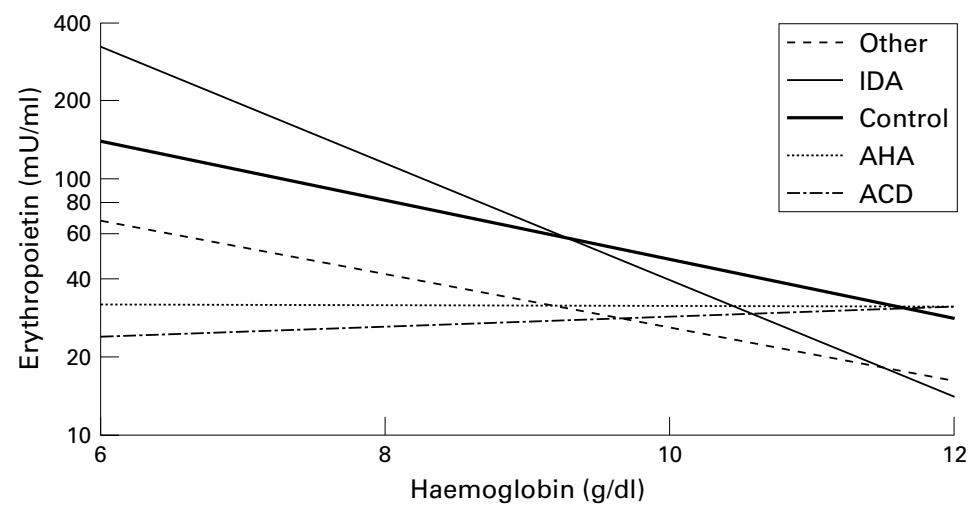

Figure 1 Relation of the $\log 10$ serum erythropoietin concentration to haemoglobin concentrations. In patients with $A C D$ and $A H A$, the slope of the regression ( $b=0.024$, $p=0.53$ and $b=-0.002, p=0.97$ respectively) was lower than in the controls $(b=-0.110$, $p=0.003)$ who included 20 patients with uncomplicated iron deficiency anaemia. ACD: anaemia of chronic disease; AHA: autoimmune haemolytic anaemia; IDA: iron deficiency anaemia.

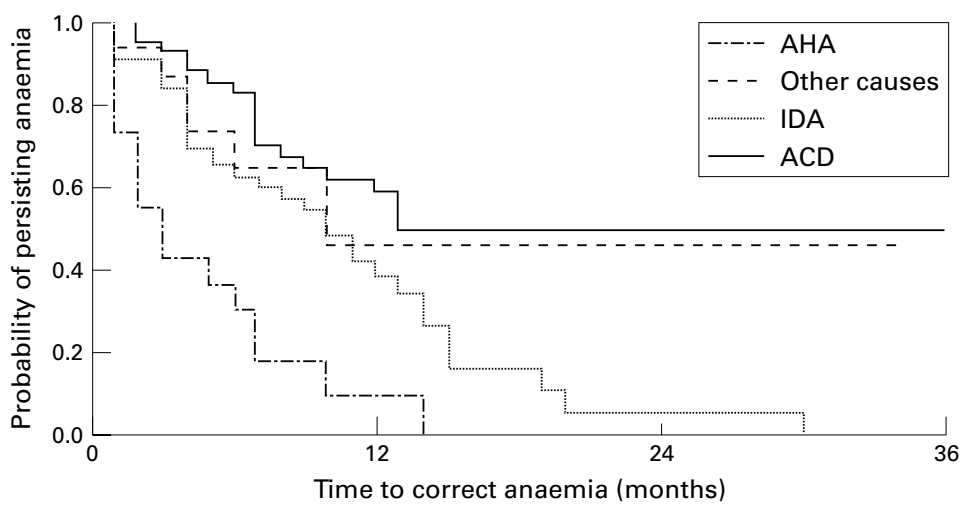

Figure 2 Kaplan-Meier plots for the time to correction of anaemia for different causes. Abbreviations as in figure 1 .

Haemoglobin concentrations were lower by $0.31 \mathrm{~g} / \mathrm{dl}$ in patients with anti-Epo reactivity, but the effect was not significant $(p>0.3)$. There was no correlation between anti-Epo antibodies and the levels of Epo (Spearman $r=0.02, \mathrm{p}=0.83)$. Mean Epo in patients with and without anti-Epo antibodies were 47.2 and $43.2 \mathrm{mU} / \mathrm{ml}$, respectively.

In univariate regression analyses investigating the slope of the logarithm of Epo over the concentrations of haemoglobin, we observed a significant increase of Epo with decreasing values of haemoglobin in IDA, but no difference in the Epo levels at different levels of haemoglobin in patients with ACD or AHA. The slope of Epo response was statistically significantly blunted compared with controls in the case of ACD $(p=0.01)$ (fig 1). The observed levels of $\log 10$ Epo were at least $25 \%$ less than the predicted $\log 10$ Epo levels based on the control group in $42.4 \%$ of the ACD cases and in $41.2 \%$ of the AHA cases, as compared with $23.7 \%$ of the IDA cases. Further analysis of Epo levels in relation with immunosuppressive treatment regimen has shown no correlation.

OUTCOME OF ANAEMIA

The four groups differed significantly in the time it took to correct the anaemia during prospective follow up (log rank $\mathrm{p}<0.0001)$ (fig 2). The median time to correct the anaemia was three months for AHA and 10 months for IDA. All patients eventually corrected their anaemia in these two groups, although some patients in the IDA group took a very long time. ACD on the other hand was unlikely to remit and more than half of the patients in this group were expected to be still anaemic three years later. The group of other causes showed a mixed behaviour with half the patients remitting at similar rates to the IDA group, while the remaining (largely the anaemia of chronic renal failure) were not corrected for long periods of time.

\section{TREATMENT}

Besides traditional corticosteroid and hydroxychloroquine regimens that were used by most patients in the study, a substantial proportion of patients had exposure to immunosuppressive regimens. During the three months before study entry, 19 patients had received cyclophosphamide, 22 azathioprine, eight methotrexate, and threee cyclosporin A, for a total of 46 patients taking any of these agents (six patients were receiving more than one of these agents). After study entry and during follow up, 50 patients received cyclophosphamide, 21 azathioprine, six methotrexate, and two cyclosporin $\mathrm{A}$, for a total of 72 patients receiving any of these agents (more than one of these medications was taken by seven patients). The use of any such immunosuppressive at study entry was associated with a prolonged time to correction of the anaemia in Kaplan-Meier analyses considering all patients (log rank $\mathrm{p}=0.011$ ). The difference was not formally statistically significant once the cause of anaemia was taken into account by stratification (log rank $p=0.18$ ). The reason was that use of immunosuppressive agents did not affect the time to recovery for patients with IDA, while it had a more pronounced effect for patients with other causes of anaemia, particularly ACD. Similar results were seen when the use of immunosuppressive agents during follow up was considered (log rank $\mathrm{p}=0.11$ unstratified, $\mathrm{p}=0.18$ stratified for cause of anaemia).

\section{Discussion}

Anaemia is a common haematological abnormality in SLE and can easily be categorised with simple laboratory tests. ACD, IDA, AHA, and chronic renal failure account for the large majority of cases. Other types of anaemia are very infrequent. Admittedly a component of ACD may also be present in patients who are categorised as having another type of anaemia. Iron deficiency in SLE patients seems to be very common and it may be the result of menorrhagia and increased gastrointestinal blood loss because of long term use of corticosteroids. Among the less frequent causes, particular notice should be made of PA. ${ }^{32}$ We observed only three cases of PA, but seven more patients had low serum cobalamin concentrations, a precursor of PA. ${ }^{33}$ This is important because widespread use of folate in SLE patients may produce deterioration of PA related neurological disease. 
SLE patients with ACD had a significantly higher disease activity as compared with the other groups, probably in part attributed to more frequent lupus nephritis. The degree of anaemia in SLE was mild, with haemoglobin concentrations usually in the 9 to $11 \mathrm{~g} / \mathrm{dl}$ range. However, anaemia tended to be more severe in patients with autoimmune cytopenias. Interestingly the severity of anaemia correlates with disease activity only among iron deficiency patients and not among ACD and AHA. AHA corresponds to acute large decreases of haemoglobin and ACD often remains the same without remitting, regardless of other disease activity components.

At a practical level, when you are faced with an SLE anaemia, our data suggest that it should be easy to differentiate among the possible mechanisms with only a few tests. If the reticulocytes are increased, a haemolytic process or acute bleeding should be the probable cause. If the reticulocytes are inadequate, you should rule out a nutritional deficiency of iron, vitamin B12, or folate. Ferritin determination suffices for diagnosing IDA. If the ferritin concentration is greater than $20 \mu \mathrm{g} / \mathrm{dl}$, IDA is virtually never present and a bone marrow examination may be considered, although the diagnostic yield may be very low and anaemia of chronic disease is the most common diagnosis of exclusion.

Our analyses suggested that patients with AHA secondary to SLE comprise a distinct group where IgG and/or IgM aCL play an important part. ${ }^{34}$ There is a controversy in the literature regarding the relative importance of IgG and IgM isotypes in AHA. Some studies have reported associations of AHA with IgM $\mathrm{aCL}$ and weaker or absent associations with the IgG isotype. ${ }^{35}{ }^{36}$ Other investigators have identified mostly IgG aCL acting as anti-red blood cell autoantibodies in SLE patients with active haemolysis. ${ }^{37}$ The result of our study is that both IgG and IgM aCL are present frequently in AHA patients, which suggests that these antibodies may play an important part in the pathogenesis of autoantibody induced red blood cell destruction. Furthermore, AHA is strongly related to low complement level and presence of anti-dsDNA antibodies. A review of the literature has indicated discrepant findings for the role of aCL antibodies in complement activation. Some researchers have found reduced levels of complement components in the presence of aCL, ${ }^{38-40}$ whereas others have found no correlation. ${ }^{41}$ It has previously been observed on SLE patients that aCL antibodies may be a factor associated with reduced complement receptor type 1 levels on the erythrocytes. ${ }^{42}$ Although there is a postulation that aCL can bind directly to erythrocyte and may fix complement to erythrocyte surface we think that our AHA population comprised patients with SLE among whom many others autoantibodies that fix complement were present (for example, anti-dsDNA antibodies), which may explain better these association.

Inflammatory cytokines such as tumour necrosis factor $\alpha$, interleukin $1 \beta$, and interferon $\gamma$, may be involved in the pathogenesis of
ACD. ${ }^{13}$ These cytokines inhibit proliferation of erythrocyte progenitors, ${ }^{43}{ }^{44}$ modulate iron metabolism, ${ }^{4546}$ and suppress Epo production. ${ }^{14}$ In a number of patients with ACD resulting from various causes other than SLE, plasma Epo concentrations were not adequate for the degree of anaemia. ${ }^{47}$ This study suggests that impaired production of Epo may be common also in SLE anaemia, in particular in patients with ACD and AHA. Lupus nephritis may partly account for impaired production of Epo in these patients. Immunohistological studies demonstrate that activated CD4 lymphocytes and macrophages that are cytokine producing cells, infiltrate the renal interstitial area in lupus nephritis. ${ }^{48}$ These cytokines may affect Epo production. ${ }^{14}$ Inflammatory cytokines not only suppress Epo, but also interfere with the ability of erythroid progenitor cells to respond to the hormone. ${ }^{15} 16$

Another kind of Epo resistance is the presence of antibodies against Epo, which inhibit the binding of Epo to its receptors and block the differentiation of erythroid progenitors. A recent study has shown that anti-Epo antibodies may be detected in SLE patients with severe anaemia and active disease.$^{17}$ In our study the prevalence of anti-Epo antibodies in SLE patients with anaemia was $21 \%$. Despite the fact that there was no correlation between the levels of Epo and the presence of anti-Epo antibodies, the possibility of the interference of the autoantibodies in the measurement of Epo cannot be excluded. Thus the binding of antiEpo antibodies to Epo may prolong the Epo half life in a manner similar to that described for interleukin $6 .{ }^{49}$ Our data suggest that anti-Epo antibodies are a marker of disease activity or of chronic disease, or both. It is unknown whether these antibodies have a biological role in inducing anaemia. An investigation in patients with human immunodeficiency virus infection have shown that anti-Epo antibodies were strongly associated with anaemia, lower haemoglobin and higher Epo levels. ${ }^{50}$ We found no correlation between these antibodies and haemoglobin or Epo levels in SLE patients with anaemia. However, the analyses in our cohort included only patients who had anaemia and therefore the ability of the study design to discern differences in haemoglobin and Epo levels was limited.

Finally, the prospective follow up of our study clearly shows marked differences in the rates of correction of anaemia depending on its cause. AHA is likely to remit soon. Additional evidence suggests that once it remits, it then has a fairly low recurrence rate. ${ }^{34}$ Iron deficiency takes longer to correct, but our data suggest that perhaps treatment is sometimes delayed. As this is a correctable type of anaemia, it should be treated promptly when diagnosed. On the other hand, ACD is unlikely to remit, although exceptions do occur. Recovery from anaemia may be particularly slow in ACD patients receiving immunosuppressive regimens, although it is not known whether the use of immunosuppressive agents in this setting is mostly the direct cause of persistent marrow 
suppression or simply a marker of greater disease activity necessitating their use.

1 Budman DR, Steinberg AD. Hematologic aspect of systemic lupus erythematosus. Current concepts. Ann Intern Med lupus erythematos

2 Vlachoyiannopoulos PG, Karasa FB, Karakostas KX, Drosos AA, Moutsopoulos HM. Systemic lupus erythematosus in Greece. Clinical features, evolution and outcome: a descriptive analysis of 292 patients. Lupus 1993;2:30312.

3 Keeling DM, Isenberg DA. Haematological manifestations of systemic lupus erythematosus. Blood Rev 1993;7:199207.

4 Nossent JC, Swaak AJ. Prevalence and significance of haematological abnormalities in patients with systemic lupus erythematosus. Q J Med 1991;80:605-12.

5 Meyer RJ, Hoffman R, Zanjani ED. Autoimmune hemolytic anemia and periodic pure red cell aplasia in systemic lupus erythematosus. Am J Med 1978;65:342-5.

6 Bailey FA, Lilly M, Bertoli LF, Ball GV. An antibody that inhibits in vitro bone marrow proliferation in a patient with systemic lupus erythematosus and aplastic anemia. Arthrisystemic lupus erythematosu

7 Junca J, Cuxart A, Tural C, Marti S. Systemic lupus eythematosus and pernicious anemia in an 82 old woman. eythematosus and pernicious

8 Costello C, Abdelaal M, Coomes EN. Pernicious anemia and systemic lupus eythematosus in a young woman. J Rheumatol 1985;12:798-9

9 Jimenez-Balderas FJ, Morales-Polanco MR, Gutierrez L. Acute sideroblastic anemia in active systemic lupus erythematosus. Lupus 1994;3:157-9.

10 Kaelin WG Jr, Spivak JL. Systemic lupus erythematosus and myelofibrosis. Am J Med 1986;81:935-8

11 Wong KF, Hui PK, Chan JK, Chan YW, Ha SY. The acute lupus hemophagocytic syndrome. Ann Intern Med 1991; 114:387-90.

12 Nesher G, Hanna VE, Moore TL, Hersh M, Osborn TG Thrombotic microangiopathic hemolytic anemia in systemic lupus erythematosus. Semin Arthritis Rheum 1994;24:165-72.

13 Means RT, Krantz SB. Progress in understanding the pathogenesis of the anemia of chronic disease. Blood 1992 pathogenesis

14 Faquin WC, Schneider TJ, Goldberg MA. Effect of inflammatoty cytokines on hypoxia-induced erythropoietin production. Blood 1992;79:1987-94.

15 Means RT Jr, Krantz SB. Inhibition of human erythroid colony-forming units by gamma interferon can be corrected by recombinant human erythropoietin. Blood 1991 78:2564-7.

16 Schooley JC, Kullgren B, Allison AC. Inhibition by interleukin-1 of the action of erythropoietin on erythroid precursors and its possible role in the pathogenesis of hypoplastic anaemias. Br J Haematol 1987;67:11-17.

17 Tzioufas AG, Kokori SI, Petrovas CI, Moutsopoulos HM. Autoantibodies to human recombinant eythropoietin in patients with systemic lupus erythematosus: correlation with anemia. Arthritis Rheum 1997;40:2212-16.

18 Casadevall N, Dupuy E, Molho-Sabatier P, Tobelem G, Varet B, Mayeux P. Autoantibodies against erythropoietin in a patient with pure red-cell aplasia. N Engl J Med 1996; in a patient

19 Tan EM, Cohen AS, Fries JF, Masi AT, McShane DJ, Rothfield NF, et al. The 1982 revised criteria for the classification of systemic lupus erythematosus. Arthritis Rheum 1982;25:1271-7.

20 Dacie JV, Lewis SM. Reference ranges and normal values. In: Dacie JV, Lewis SM, ed, Practical haematology. New York: Churchill Livingstone, 1991:9-17.

21 Vitali C, Bencivelli W, Isenberg DA, Smolen JS, Snaith ML, Sciuto $\mathrm{M}$, et al. Disease activity in systemic lupus eythematosus: report of the Consensus Study Group of the European Workshop for Rheumatology Research. Identification of the variables indicative of disease activity and their use in the development of an activity score. The European Consensus Study Group for Disease Activity in SLE. Clin Exp Rheumatol 1992;10:541-7.

22 Sears DA. Anemia of chronic disease. Med Clin North Am 1992;76:567-79.

23 Carmel R, Johnson CS, Weiner JM. Pernicious anemia in Latin Americans is not a disease of the elderly. Arch Intern Med 1987;147:1995-6.

24 Weatheral DJ. The thalassemia. In: Williams WJ, Beutler E, Erslev AJ, Lichtman MA, eds, Hematology. New York: McGraw-Hill, 1990:510-39

25 Erslev AJ. Anemia of chronic disorders. In: Williams WJ, Beutler E, Erslev AJ, Lichtman MA, eds, Hematology. New York: McGraw-Hill, 1990:540-6.

26 Packman CH, Leddy JP. Acquired hemolytic anemia due to warm-reacting autoantibodies. In: Williams WJ, Beutler E, Erslev AJ, Lichtman MA, eds. Hematology. New York: McGraw-Hill, 1990:666-75.
27 Erslev AJ. Pure red cell aplasia. In: Williams WJ, Beutler E, Erslev AJ, Lichtman MA, eds, Hematology. New York: Mcraw-Hill, 1990:430-8

28 Tzioufas AG, Manoussakis MN, Drosos AA, Silis G, Gharavi AE, Moutsopoulos HM. Enzyme immunoassays for the detection of IgG and IgM anti-dsDNA antibodies: clinical significance and specificity. Clin Exp Rheumatol 1987;5: 247-53.

29 Manoussakis MN, Tzioufas AG Silis MP, Pange PJ, Goudevenos J, Moutsopoulos HM. High prevalence of anticardiolipin and other autoantibodies in a healthy elderly population. Clin Exp Immunol 1987;69:557-65.

30 Beguin Y, Clemons GK, Pootrakul P, Fillet G. Quantitative assessment of erythropoiesis and functional classification of anemia based on measurements of serum transferrin receptor and erythropoietin. Blood 1993;81:1067-76.

31 Churg J, Sobin LH. Lupus nephritis. In: Churg J, ed. Renal disease. Classification and atlas of glomerular disease. New York: Igaku-Shoin, 1982:127-49.

32 Carmel R. Prevalence of undiagnosed pernicious anemia in the elderly. Arch Intern Med 1996;156:1097-100.

33 Herbert V. Don't ignore low serum covalamin (vitamin B12) levels. Arch Intern Med 1988;148:1705-7.

34 Kokori IG, Ioannidis JPA, Voulgarelis M, Tzioufas AG, Moutsopoulos HM. Autoimmune hemolytic anemia in patients with systemic lupus erythematosus. Am J Med (in press).

35 Lopez-Soto A, Cervera R, Font J, Bove A, Reverter JC, Munoz FJ, et al. Isotype distribution and clinical significance of antibodies to cardiolipin, phosphatidic acid, phosphatidylinositol and phosphatidylserine in systemic lupus erythematosus: prospective analysis of a series of 92 patients. Clin Exp Rheumatol 1997;15:143-9.

36 Deleze M, Alargon-Segovia D, Oria CV, Sanchez-Guerrero J, Fernandez-Dominguez L, Gomez-Pacheco L, et al. Hemocytopenia in systemic lupus eythematosus. Relationship to antiphospholipid antibodies. J Rheumatol 1989;16: 926-30

37 Sthoeger Z, Sthoeger D, Green L, Geltner D. The role of anticardiolipin autoantibodies in the pathogenesis of autoimmune hemolytic anemia in systemic lupus erythematosus. J Rheumatol 1993;20:2058-61.

38 Norberg R, Nived O, Sturfelt G, Unander M, Arfors L. Anticardiolipin and complement activation: relation to clinical symptoms. J Rheumatol 1987;14 (suppl 13):14953.

39 Hazeltine M, Rauch J, Danoff D, Esdaile JM, Tannenbaum $\mathrm{H}$. Antiphospholipid antibodies in systemic lupus erythematosus: evidence of an association with positive Coombs' and hypocomplementemia. J Rheumatol 1988; 15:80-6.

40 Arvieux J, Roussel B, Ponard D, Colomb MG. Reactivity patterns of anti-phospholipid antibodies in systemic lupus rythematosus sera in relation to erythrocyte binding and complement activation. Clin Exp Immunol 1991;84:46671

41 Santiago MB, Gaburo N Jr, de Oliveira RM, Cossermelli W. Complement activation by anticardiolipin antibodies. Ann Rheum Dis 1991;50:249-50.

42 Hammond A, Rudge AC, Loizou S, Bowcock SJ, Walport MJ. Reduced numbers of complement receptor type 1 on erythrocytes are associated with increased levels of anticardiolipin antibodies. Findings in patients with systemic lupus erythematosus and the antiphospholipid syndrome. Arthritis Rheum 1989;32:259-64.

43 Means RT Jr, Dessypris EN, Krantz SB. Inhibition of human erythroid colony-forming unit by interleukin-1 is mediated by gamma interferon. J Cell Physiol 1992;150: 59-64.

44 Mamus SW, Beck-Schroeder S, Zanjani ED. Suppression of normal human erythropoiesis by gamma interferon in vitro. Role of monocytes and T lymphocytes. J Clin Invest 1985; 75:1496-503.

45 Jongen-Lavrencic M, Peeters HR, Vreugdenhil G, Swaak AJ. Interaction of inflammatory cytokines and erythropoietin in iron metabolism and erythropoiesis in anemia of chronic disease. Clin Rheumatol 1995;14:519-25.

46 Hirayama M, Kohgo Y, Kondo H, Shintani N, Fujikawa K, Sasaki K, et al. Regulation of iron metabolism in HepG2 cells: a possible role for cytokines in the hepatic deposition of iron. Hepatology 1993;18:874-80.

47 Barosi G. Inadequate erythropoietin response to anemia: definition and clinical relevance. Ann Hematol 1994;68: $215-23$.

48 Caligaris-Cappio F, Bergui L, Tesio L, Ziano R, Camussi G. HLA-DR+T cells of the Leu3 (helper) type infiltrate the kidneys of patients with lupus eythematosus. Clin Exp Immunol 1985;59:185-9.

49 Bendtzen K, Hansen MB, Ross CHR, Svenson M. Cytokine autoantibodies. In: Peter J, Shoenfeld Y, eds. Autoantibodies. Amsterdam: Elsevier Science, 1996

50 Sipsas N, Kokori SIG, Ioannidis JPA, Kyriaki D, Tzioufas AG, Kordossis T. Circulating autoantibodies to erythropoietin are associated with HIV-1 related anemia. J Infect Dis $1999 ; 180: 2044-7$ 